\title{
社会資本整備論としてのランドスケープ研究
}

\section{Landscape studies based on the Analysis of the Establishment of Infrastructure}

\section{石川 幹子* Mikiko ISIKAWA}

\section{1.はじめに}

社会資本とは, 道路, 港湾, 鉄道, 通信, 電力, 上下水 道, 公園など, 人々の生活と産業の基盤となる公共財の総 称である。一般に生産, 消費にかかわる資本は, 私的所有 が認められるものと，社会の共有の資本として私有が認め られないものとに分かれる。後者は，第一に稀少資源，第 二にそこから生み出されるサーヴィスが市民の基本的権利 にかかわり，市場機構を通じて分配することがふさわしく ないもの等が該当する。わが国の社会資本整備は, 明治期 以来, 産業活動の基盤となる分野においては手厚かったが, 生活環境の基盤整備には著しい立ち後れがみられる。この 間の日本経済の華やかな成長にもかかわらず, 生活の豊か さが実感として感じることができないのは,このような社 会資本整備の偏りが大きな要因となっている。

日本における都市公園の整備水準は, 一人当たり $6.5 \mathrm{~m}^{2}$ （平成 4 年度）であり, 諸外国における整備水準と比較し ても, 著しく低いことは論を待たない。特に, 大都市圏に おいては更に低い。このような社会資本整備の水準につい て,これまで私たちは, 個々の数値を比較検討し, 目標設 定をするということになじんできた。しかしながら, 社会 資本整備という，長期にわたる政策及び公共投資の蓄積が 課題となる領域では, 社会資本形成のメカニズムに関する 基礎的研究の蓄積が必要である。

\section{2. 方法論の枠組みと具体的展開}

社会資本整備論に関する方法論は，大きく四つに分けら れる。第一は社会資本整備のプロセスの歴史的研究, 第二 は計画論と政策論に関する研究, 第三は財源問題, 第四は 維持管理・運営等のソフトのシステムを組み込んだ新しい 社会資本整備のシステムに関する研究である。

このうち, 最も研究の蓄積がみられるのが, 社会資本整 備のプロセスに関する歷史的研究である。堀江興 ${ }^{1)}$ (東京 の幹線街路形成について検証し, 松浦茂樹 ${ }^{2}$ は近代土木技 術と明治期における国土開発について論じた。石川幹子3) は，アメリカにおけるパークシステムの展開を都市形成と
の関係から考察し，近代都市計画の成立に果たした役割に ついて論じた。

計画論及び政策論では, 寺西弘, 古川公毅4)が東京にお ける都市計画の制度と実態の変遷について検証している。 ランドスケープの分野では, 個別の政策に関する研究は, 風致地区等については充実してきているが，実態と対応さ せた分析，および計画論と政策論を連動させた研究が今後 必要である。特に, 緑のマスタープランについては, 昭和 52 年に制度化されてより, 具体的展開を踏まえ, この間 様々の改良珈えられてきた。平成 6 年の都市緑地保全法 の改正に伴い緑のマスタープランは都市緑化推進計画と一 体化され「緑の基本計画」として策定されることとなった。 こうした節目にあたることから, 緑のマスタープランの計 画論の特質および政策との連動等について検証する時期に きていると考える。

財源問題については，歷史的研究に蓄積がみられる。鈴 木栄基 ${ }^{5}$ は日本における超過収用制度について実証研究を しており, 石田頼房 ${ }^{6)}$ は京都における受益者負担金問題を とりあげている。また, 馬場俊介 ${ }^{7}$ は, 名古屋における道 路整備とその財源について論じた。ランドスケープの分野 では, 財源に関してまだまとまった研究はなされていない。 欧米の公園緑地整備が都市基盤形成と連動して計画され, 開発利益を還元することにより土地取得の先行投資を回収 することを定石としてきたことを考えあわせる時, 日本の 公園緑地の整備のプロセスを財源問題から検証していくこ とは重要な課題であると考える。

管理運営のシステムを組み込んだ新しい社会資本整備の 在り方は，今後の大きな研究領域である。これまで社会資 本整備は空間的実態を有するあののみを対象に論じられて きた傾向が強い。しかし, 社会資本は, それから生み出さ れるサーヴィスおよびそれを使用する市民の存在により， 始めてその効用が生じる。公園緑地は特に生命系の社会資 本であり，持続的サーヴィスを提供していくためには，公 園緑地の社会的費用をだれが，どのように支払うのか，ま た，維持管理・運営のシステムに市民を包含した新しい仕

*東京工業大学工学部 
組みにはどのような可能性があるのか等の検討が必要であ る。このような, 社会的制度と密接な関連をもった新しい 社会資本整備の在り方として, 宇沢弘文 ${ }^{8,9}$ 9 $は 「$ 社会的共 通資本」という概念の提示を行っている。

\section{3. 社会資本整備論としてのランドスケープ研究の事例}

では, 社会資本整備論としてのランドスケープ研究は, 具体的にどのようなものであるかの一例を，筆者のパーク システム研究を事例として簡潔に述べる。

19 世紀中葉から 20 世紀初頭にかけて，欧米の大都市で は産業革命の進展に伴う都市への人口の集中により深刻な 都市問題が生じた。不良住宅への稠密居住, 市街地の外延 的拡大等の諸問題に対し, 様々な緑地が都市基盤施設とし て整備された。その手法は, 大きく三つに分けられる。第 一は, 封建都市の構造に改造を加えると共に, 王侯貴族の 庭園, 狩猙地等を開放し，前時代のストックを近代都市に おける緑地に転化させたもの。第二は，このようなストッ クをもたない新大陸アメリカにおいて，市街地開発之公園 緑地の整備・保全を一体的に行い，新しい都市秩序を生み 出したもので，これをパークシステムという。第三は，既 存市街地の改良ではなく, 郊外に都市と田園の共存する理 想都市を求めたものであり, エベネザー・ハワードにより 提唱された田園都市運動である。これら三つの手法は, 出 目は異なるものの互いに影響を受けつつ, 近代都市計画に おける緑地計画の枠組みをつくってきた。

筆者の研究は, このうちアメリカで誕生したパークシス テムを対象とし, 計画思想, 実施過程, 財源, 計画技術等 の視点から検討を加え都市形成における役割を検証し，公 園と広幅員街路のシステム(パークシステム)の社会資本と しての意義について論じたものであり，以下の知見を得た。 (1) 計画思想

パークシステムは, 正確には “公園と広幅員街路の系統 (Parks, Boulvards and Parkways System)”である。 これは, 従来わが国において理解されてきた公園と公園を 結ぶレクリエーション計画に基づく緑地ではなく，良質の 都市基盤（大規模公園，ブールヴァール，パークウェイ） を導入することにより計画的市街地開発を行い, 合わせて 良好な自然環境の保全をめざしたあのであった。大規模公 園は大気を浄化する “都市の肺” として, 広幅員街路は火 災の延焼を防ぐ防火帯として, 河川, 湖沼沿いの緑地は水

\section{主要文献}

1 ) 堀江興 (1990): 東京の幹線道形成に関する史的研究, 学位論文

2 ）松浦茂樹（1992）: 明治の国土開発史一近代土木技術の礎, 鹿島出版会

3 ）石川幹子 (1994): パークシステムの成立と展開に関する歴 史的研究, 学位論文

4 ）寺西弘文・古川公毅（1993）: 東京都市計画の制度と実態の 変遷, 土木史研究 13 号

5 ）鈴木栄基（1991）: 日本近代都市計画史における超過収用制
資源保全を目的とし確保された。

(2) 実施過程と財源

パークシステムの導入を実現に移したのは各都市の市民 運動であり, 世論を喚起する媒体としては新聞等が大きな 貢献をした。財源は, 都市ごとの財政基盤により多様であ り, 様々な工夫がみられた。債券を発行する能力のあった 大都市では (ニューヨーク, ボストン等), 基本的に公園 債を発行するとともに，公園隣接地に受益者負担金を課し， 初期投資を回収した。シカゴ等の新興都市では，公園区を 設定し, 特別税として公園及びブールヴァール税を導入し た。カンザス・シティなどの債券発行が制限されていた都 市では，公園区を設定し特別付加金を課すとともに，初期 投資に必要とされる資金の確保のために特別付加金債を発 行した。また, 首都ワシントンのように, 市単独の基盤整 備により財政が破綻し, 連邦政府が代行することとなった 都市むある。

このように, 手法は異なるもののパークシステムが都市 基盤施設として幅広く導入されたのは, その経済的効果 （固定資産税の評価額の增税に伴う税収の增大及び良好な 市街地開発の誘導)が, 高く評価されたからにほかならない。 (3) 計画技術

パークシステムの導入は, 河川, 湖沼, 段丘崖, 樹林地 など自然環境の立地特性に基づく基盤整備であったため, それまでの格子型街路網を基本とするアメリカの都市構造 に質的変化をもたらした。また，パークシステム計画論の 特質は, 拡大する市街地の計画的整備と土地利用の制御に あり,これは, 20 世紀初頭の都市計画の大きな課題でも あった。アメリカでは 20 世紀初頭まで, 都市計画という 職業領域は存在していなかったが, 約半世紀をかけて培わ れたパークシステム整備に関わる計画論, 事業論の蓄積は, 近代都市計画の領域の誕生の礎となったのである。

以上, パークシステムという切りロから社会資本整備論 としてのランドスケープ研究の一端を示した。20世紀を代 表する緑地計画論としては，このほかに，グリーン・ベル 卜論, 田園都市論, 生態学を基礎とする土地利用計画論等 がある。これらの計画論の果たした歷史的役割，今日的意 義を明確にする上で, 社会資本整備論からのアプローチは 極めて重要である。それは, 今日の緑地構造の特質および 計画論, 施策の課題を明瞭にすると共に, 新たな展開に向 けての道しるべとなるからである。

度に関する研究, 学位論文

6 ) 石田頼房 (1987): 日本近代都市計画史研究, 柏書房

7 ) 馬場俊介（1990：明治大正期名古屋の道路整備とその財源, 土木史研究 10 号

8 ）宇沢弘文 (1994): 宇沢弘文著作集第 1 巻, 社会的共通資本 の概念, 岩波書店

9 ）宇沢弘文・茂木愛一郎編（1994）：社会的共通資本，東京大 学出版会 